\title{
Neuronal loss in the hippocampus in Huntington's disease: a comparison with HIV infection
}

Edward Spargo, Ian P Everall, Peter L Lantos

\begin{abstract}
The hippocampus is usually affected in primary dementias and the pathological changes may be severe. Knowledge of hippocampal pathology in HIV infection and Huntington's disease (HD), however, is extremely limited. A stereological technique (the optical "disector") has been used to assess neuronal populations in four areas of the hippocampus in 11 patients with HIV infection and in nine patients with HD. The HIV patients died without opportunistic infections or neoplasms affecting the brain; they had HIV encephalitis or minimal changes. The HD cases were all clinically diagnosed, had a positive family history and showed the characteristic lesions in the caudate nucleus. The neuronal counts were compared with those in nine controls. In the granule cell layer of the dentate, CA3 and CA4, there was no significant difference in the neuronal numerical density between the three groups. A striking difference between the HIV and HD groups was seen in the CA1 region. The neuronal numerical density in the CA1 area was significantly lower in the HD patients than in either the HIV patients or the controls (mean (SD) $37.5(5.0)$; 70.1 (13.4); $57.9(15.4) \times 10^{3}$ per $\mathrm{mm}^{3}, \mathrm{p}<$ 0.001 (Students' $t$ test)). This difference represents a neuronal loss of $35 \%$. In all four hippocampal areas the neuronal density was higher in the HIV group than in the controls but the differences were not significant and can be explained by the higher average age of the control group. These findings contribute to the understanding of the mechanism of dementia in both AIDS and in Huntington's disease.
\end{abstract}

$(\Im$ Neurol Neurosurg Psychiatry 1993;56:487-491)

Department of Neuropathology, Institute of Psychiatry, DeCrespigny Park, London SE5 8AF, UK E Spargo

I P Everall

P L Lantos

Correspondence to: Dr E Spargo.

Received 9 June 1992 and in revised form 7 August 1992.

Accepted 18 August 1992
Damage to the nervous system is a major consequence of infection with human immunodeficiency virus 1 (HIV-1) which results in a variety of neurological manifestations. ${ }^{12}$ Abnormalities in the central and peripheral nervous system are found at necropsy in over $95 \%$ of patients with the acquired immunodeficiency syndrome (AIDS). ${ }^{34}$ The most common neuropsychiatric disorder is HIV associated dementia, ${ }^{5}$ characterised by progressive cognitive impairment, personality change, and motor disturbance. ${ }^{16}$ The cause of this dementia has not been established. However, in many of those with HIV associated dementia, encephalitis is found at necropsy and one study has shown the degree of dementia to be directly associated with the severity of inflammation. ${ }^{7}$

The role of this encephalitic process, which affects about $40 \%$ of patients, ${ }^{8}$ in the development of dementia is uncertain. A recent study has shown that there is a neuronal loss of up to $38 \%$ in the superior frontal gyrus of a group of HIV-infected patients, all but one of whom died from AIDS. ${ }^{9}$ Moreover, this neuronal loss occurred in the same proportions whether HIV encephalitis was present or not. These findings raised the possibility of a dual pathogenetic mechanism of HIV infection in the brain in that neuronal loss and HIV encephalitis may represent two independent processes of damage, one a toxic effect and the other an inflammatory response. In addition, the finding of neuronal loss from the frontal cortex does not support the view that HIV associated dementia is subcortical.

Similar cortical neuronal loss has been reported in the frontal cortex in Huntington's disease (HD). ${ }^{1011}$ While the abnormal movements in HD have been ascribed to the anatomical and neurochemical abnormalities in the neostriatum, the underlying basis for the neuropsychiatric symptoms and dementia remains unknown. ${ }^{12}$

Neuropathologically, the dementia associated with HIV or with HD can each be classified as a primary dementia ${ }^{13}$ as structural alterations in the brain, notably cell loss from the frontal cortex, have been reported in both. ${ }^{9-11}$

The early clinical presentation of dementia associated with $\mathrm{HIV}$ infection ${ }^{2}$ and $\mathrm{HD}^{14}$ includes progressive cognitive impairment involving memory deficits and mental slowing. In addition, in both of these diseases the onset of dementia frequently occurs in early adult life, unlike Alzheimer's disease in which dementia presents at a much later age. HIV infection and HD also differ from Alzheimer's disease in that neither show the characteristic neuropathological lesions of Alzheimer's disease namely, senile plaques and neurofibrillary tangles. However, it is unclear whether the dementia in HIV infection and HD is solely attributable to the changes in the frontal cortex, and raises the question whether cell loss is seen in other areas of the cortex in either or both disorders.

The hippocampus is usually affected in 
primary dementias and severe pathological changes develop in both Alzheimer's disease and in Pick's disease. Our knowledge of hippocampal pathology in HIV infection and $\mathrm{HD}$, however, is extremely limited.

A new, statistically robust stereological probe known as the optical "disector" allows three-dimensional estimation of cell number, ${ }^{15}$ thus enabling a more precise assessment of neuronal populations. The aim of this study is to quantitatively assess neuronal populations in four areas of the hippocampus to clarify the neuropathological substrate of dementia.

\section{Methods}

Hippocampal cell counts were carried out in three groups of subjects: HIV-infected patients $(n=11), \mathrm{HD}$ patients $(n=9)$ and controls $(n=9)$. All the subjects were male. Eleven consecutive brains, with no evidence of HIV associated opportunistic infection or neoplasm, were selected for the study from the Medical Research Council Central AIDS Brain Tissue Bank (Department of Neuropathology, Institute of Psychiatry). The HIV infected cases comprised two subgroups. In the first subgroup HIV encephalitis was the sole neuropathological diagnosis (five cases: $1,2,4,5$, and 11 ), while the remaining six brains, forming the second subgroup, showed only minimal changes such as slight astrocytosis and perivascular cuffing by mononuclear cells. Ten of the 11 subjects had died with a clinical diagnosis of AIDS, and one (case 9) died, while still HIV positive, from cardiac valvular complications of osteogenesis imperfecta.

Table 1 Patient details

\begin{tabular}{|c|c|c|c|c|}
\hline Case no & Age (y) & Sex & Cause of death & Brain weight (g) \\
\hline $\begin{array}{l}\text { Controls } \\
\text { C1 } \\
\text { C2 } \\
\text { C3 } \\
\text { C4 } \\
\text { C5 } \\
\text { C6 } \\
\text { C7 } \\
\text { C8 } \\
\text { C9 }\end{array}$ & $\begin{array}{l}35 \\
44 \\
47 \\
51 \\
60 \\
20 \\
57 \\
48 \\
63\end{array}$ & $\begin{array}{l}\mathbf{M} \\
\mathbf{M} \\
\mathbf{M} \\
\mathbf{M} \\
\mathbf{M} \\
\mathbf{M} \\
\mathbf{M} \\
\mathbf{M} \\
\mathbf{M}\end{array}$ & $\begin{array}{l}\text { Bronchopneumonia, PKU } \\
\text { Pontine Haemorrhage } \\
\text { Gastro-intestinal haemorrhage } \\
\text { Chronic cardiomyopathy } \\
\text { Myocardial infarction } \\
\text { Suicide } \\
\text { Myocardial infarction } \\
\text { Ruptured aortic aneurism } \\
\text { Not specified }\end{array}$ & $\begin{array}{l}1253 \\
1473 \\
1375 \\
1367 \\
1187 \\
\overline{1248} \\
1312 \\
1345\end{array}$ \\
\hline Mean (SD) & \multicolumn{3}{|c|}{$47 \cdot 2(13 \cdot 3)$} & $1320(90)$ \\
\hline $\begin{array}{c}\text { HIV Infected } \\
\text { H1 } \\
\text { H2 } \\
\text { H3 } \\
\text { H4 } \\
\text { H5 } \\
\text { H6 } \\
\text { H7 } \\
\text { H8 } \\
\text { H9 } \\
\text { H10 } \\
\text { H11 }\end{array}$ & $\begin{array}{l}47 \\
48 \\
22 \\
42 \\
34 \\
37 \\
30 \\
30 \\
32 \\
38 \\
38\end{array}$ & $\begin{array}{l}\mathbf{M} \\
\mathbf{M} \\
\mathbf{M} \\
\mathbf{M} \\
\mathbf{M} \\
\mathbf{M} \\
\mathbf{M} \\
\mathbf{M} \\
\mathbf{M} \\
\mathbf{M} \\
\mathbf{M}\end{array}$ & $\begin{array}{l}\text { Bronchopneumonia } \\
\text { Encephalopathy } \\
\text { Pneumocystis pneumonia } \\
\text { MAI pneumonia } \\
\text { Not specified } \\
\text { Mitral valve disease } \\
\text { Not specified } \\
\text { Pneumocystis pneumonia } \\
\text { Bronchopneumonia } \\
\text { Pneumocystis pneumonia } \\
\text { Pneumocystis pneumonia }\end{array}$ & $\begin{array}{l}1540 \\
1355 \\
1531 \\
1388 \\
= \\
\overline{1540} \\
1315 \\
1450 \\
1530 \\
-\end{array}$ \\
\hline Mean (SD) & \multicolumn{3}{|c|}{$37 \cdot 3(7 \cdot 6)$} & $1445(94)$ \\
\hline $\begin{array}{l}\text { Huntington's } \\
\text { HD1 } \\
\text { HD2 } \\
\text { HD3 } \\
\text { HD4 } \\
\text { HD5 } \\
\text { HD6 } \\
\text { HD7 } \\
\text { HD8 } \\
\text { HD9 }\end{array}$ & $\begin{array}{l}\text { isease } \\
45 \\
53 \\
71 \\
50 \\
46 \\
67 \\
31 \\
63 \\
27\end{array}$ & $\begin{array}{l}\mathbf{M} \\
\mathbf{M} \\
\mathbf{M} \\
\mathbf{M} \\
\mathbf{M} \\
\mathbf{M} \\
\mathbf{M} \\
\mathbf{M} \\
\mathbf{M}\end{array}$ & $\begin{array}{l}\text { Suicide (hanging) } \\
\text { Aspiration pneumonia } \\
\text { Cerebral thrombosis } \\
\text { Died in fire } \\
\text { Coronary insufficiency } \\
\text { Bronchopneumonia } \\
\text { Bilateral adrenal haemorrhage } \\
\text { Myocardial degeneration } \\
\text { Pneumonia }\end{array}$ & $\begin{array}{l}1594 \\
1399 \\
1520 \\
1293 \\
1367 \\
1155 \\
1285 \\
1131\end{array}$ \\
\hline Mean (SD) & \multicolumn{3}{|c|}{$50 \cdot 3(15 \cdot 2)$} & $1343(162)$ \\
\hline
\end{tabular}

The nine Huntington's disease cases were selected from the brain collection in the Department of Neuropathology, Institute of Psychiatry. All subjects were clinically diagnosed as HD during life, had a positive family history, and post mortem examination of the brains showed the characteristic lesions in the caudate nucleus. The age of onset was known in seven of the cases [mean (SD) $=39.6$ $(16 \cdot 2)$ years] and, excluding case 1 who committed suicide, the mean duration of the disease was $9.7(4.5)$ years. The control group comprised nine patients: eight died of systemic illness, without cerebral pathology, whilst one had a pontine haemorrhage which did not affect the cerebral hemispheres. Although the cause of death in many of the subjects, in all groups, would have produced hypoxia there was no classic neuropathological evidence of anoxia (for example, pyknotic and eosinophilic neurons especially in CA1 region of the hippocampus). Similar findings have been reported in HIV encephalitis by other workers. ${ }^{16}$

Although the HIV status of the HD group and controls could not be ascertained, none had any evidence of being in an at-risk group. The mean (SD) age was $37.3(7.6)$ in the HIV group, $50.3(15.2)$ in the HD group and $47 \cdot 2(13.3)$ years in the controls, but the differences were not statistically significant. Fixed brain weights were known for 24 of the 29 subjects and there were no significant differences between the mean fixed brain weights of the three groups (table 1 shows patient details).

Blocks were taken from the hippocampus at the level of the lateral geniculate body. The tissue was embedded in paraffin wax, on a 5 day processing schedule. The resulting tissue shrinkage was about $10 \%$ of the section area, but it did not differ significantly between groups. Sections were cut at $20 \mu \mathrm{m}$, stained with cresyl-violet and coded for assessment. Neuronal densities were quantified in the granule cell layer of the dentate, and in the CA1, CA3 and CA4 fields of the hippocampus. These anatomically discrete ${ }^{17}$ areas were delineated in accord with an earlier study. ${ }^{18}$ Quantitation was carried out using a stereological technique known as the optical "disector". ${ }^{19}$

\section{Results}

The neuronal numerical density in the four areas of the hippocampus for each subject are shown separately in tables $2-5$, and group means are summarised in table 6 . The mean neuronal numerical density for the control group is similar to reported values in a previous study that estimated neuronal numbers in the hippocampus. ${ }^{18}$

Analysis of variance was carried out on the data for each of the subject groups for each area quantified and this shows a striking difference between the HIV infected subjects and those with Huntington's disease. In the HIV group there is no significant difference in the neuronal numerical density in any of the 
Table 2 Neuronal numerical density $\left(\times 10^{3}\right.$ per $\left.\mathrm{mm}^{3}\right)$ dentate.

\begin{tabular}{|c|c|c|c|c|c|}
\hline \multicolumn{2}{|l|}{ Control group } & \multicolumn{2}{|c|}{ HIV Group } & \multicolumn{2}{|c|}{ HD Group } \\
\hline $\begin{array}{l}\text { Patient } \\
\text { Number }\end{array}$ & $\begin{array}{l}\text { Number of } \\
\text { neurons }\end{array}$ & $\begin{array}{l}\text { Patient } \\
\text { number }\end{array}$ & $\begin{array}{l}\text { Number of } \\
\text { neurons }\end{array}$ & $\begin{array}{l}\text { Patient } \\
\text { number }\end{array}$ & $\begin{array}{l}\text { Number of } \\
\text { neurons }\end{array}$ \\
\hline $\begin{array}{l}\text { C1 } \\
\text { C2 } \\
\text { C3 } \\
\text { C4 } \\
\text { C5 } \\
\text { C6 } \\
\text { C7 } \\
\text { C8 } \\
\text { C9 }\end{array}$ & $\begin{array}{l}372 \\
328 \\
372 \\
220 \\
520 \\
307 \\
360 \\
492 \\
532\end{array}$ & $\begin{array}{l}\text { H1 } \\
\text { H2 } \\
\text { H3 } \\
\text { H4 } \\
\text { H5 } \\
\text { H6 } \\
\text { H7 } \\
\text { H8 } \\
\text { H9 } \\
\text { H10 } \\
\text { H11 }\end{array}$ & $\begin{array}{l}408 \\
336 \\
484 \\
492 \\
580 \\
396 \\
392 \\
620 \\
368 \\
552 \\
348 \\
11 \\
452(99)\end{array}$ & $\begin{array}{l}\text { HD1 } \\
\text { HD2 } \\
\text { HD3 } \\
\text { HD4 } \\
\text { HD5 } \\
\text { HD6 } \\
\text { HD7 } \\
\text { HD8 } \\
\text { HD9 }\end{array}$ & $\begin{array}{l}356 \\
392 \\
392 \\
364 \\
360 \\
372 \\
392 \\
392 \\
380 \\
\\
9 \\
378(15)\end{array}$ \\
\hline
\end{tabular}

Table 3 Neuronal numerical density $\left(\times 10^{3}\right.$ per $\left.\mathrm{mm}^{3}\right) \mathrm{CA1}$ region

\begin{tabular}{|c|c|c|c|c|c|}
\hline \multicolumn{2}{|l|}{ Control group } & \multicolumn{2}{|c|}{ HIV Group } & \multicolumn{2}{|l|}{ HD Group } \\
\hline $\begin{array}{l}\text { Patient } \\
\text { Number }\end{array}$ & $\begin{array}{l}\text { Number of } \\
\text { neurons }\end{array}$ & $\begin{array}{l}\text { Patient } \\
\text { number }\end{array}$ & $\begin{array}{l}\text { Number of } \\
\text { neurons }\end{array}$ & $\begin{array}{l}\text { Patient } \\
\text { number }\end{array}$ & $\begin{array}{l}\text { Number of } \\
\text { neurons }\end{array}$ \\
\hline $\begin{array}{l}\text { C1 } \\
\text { C2 } \\
\text { C3 } \\
\text { C4 } \\
\text { C5 } \\
\text { C6 } \\
\text { C7 } \\
\text { C8 } \\
\text { C9 }\end{array}$ & $\begin{array}{l}\mathbf{4 8} \cdot 0 \\
\mathbf{7 8} \cdot 7 \\
\mathbf{4 4} \cdot 0 \\
50 \cdot 7 \\
\mathbf{7 0 \cdot 7} \\
\mathbf{4 6 \cdot 7} \\
\mathbf{4 0 \cdot 0} \\
80 \cdot 0 \\
\mathbf{6 2 . 7}\end{array}$ & $\begin{array}{l}\mathrm{H} 1 \\
\mathrm{H} 2 \\
\mathrm{H} 3 \\
\mathrm{H} 4 \\
\mathrm{H} 5 \\
\mathrm{H} 6 \\
\mathrm{H} 7 \\
\mathrm{H} 8 \\
\mathrm{H} 9 \\
\mathrm{H} 10 \\
\text { H11 }\end{array}$ & $\begin{array}{l}80 \cdot 0 \\
57 \cdot 3 \\
90 \cdot 7 \\
61 \cdot 3 \\
60 \cdot 0 \\
72 \cdot 0 \\
62 \cdot 7 \\
86 \cdot 7 \\
72 \cdot 0 \\
80 \cdot 0 \\
48 \cdot 0 \\
11 \\
70 \cdot 1(13 \cdot 4)\end{array}$ & $\begin{array}{l}\text { HD1 } \\
\text { HD2 } \\
\text { HD3 } \\
\text { HD4 } \\
\text { HD5 } \\
\text { HD6 } \\
\text { HD7 } \\
\text { HD8 } \\
\text { HD9 }\end{array}$ & $\begin{array}{l}33 \cdot 3 \\
\mathbf{4 4} \cdot 0 \\
\mathbf{4 2} \cdot 7 \\
40 \cdot 0 \\
37 \cdot 3 \\
32 \cdot 0 \\
29 \cdot 3 \\
38 \cdot 7 \\
40 \cdot 0\end{array}$ \\
\hline
\end{tabular}

${ }_{\star \star \star}$ Significantly different from control $t=4 \cdot 19 ; \mathrm{p}<0.001$ (Student's $t$-test).

Table 4 Neuronal numerical density $\left(\times 10^{3}\right.$ per $\left.\mathrm{mm}^{3}\right) \mathrm{CA} 3$ region

\begin{tabular}{|c|c|c|c|c|c|}
\hline \multicolumn{2}{|l|}{ Control group } & \multicolumn{2}{|c|}{ HIV Group } & \multicolumn{2}{|c|}{ HD Group } \\
\hline $\begin{array}{l}\text { Patient } \\
\text { Number }\end{array}$ & $\begin{array}{l}\text { Number of } \\
\text { neurons }\end{array}$ & $\begin{array}{l}\text { Patient } \\
\text { number }\end{array}$ & $\begin{array}{l}\text { Number of } \\
\text { neurons }\end{array}$ & $\begin{array}{l}\text { Patient } \\
\text { number }\end{array}$ & $\begin{array}{l}\text { Number of } \\
\text { neurons }\end{array}$ \\
\hline $\begin{array}{l}\text { C1 } \\
\text { C2 } \\
\text { C3 } \\
\text { C4 } \\
\text { C5 } \\
\text { C6 } \\
\text { C7 } \\
\text { C8 } \\
\text { C9 }\end{array}$ & $\begin{array}{l}49 \cdot 3 \\
50 \cdot 7 \\
44 \cdot 0 \\
41 \cdot 3 \\
38 \cdot 7 \\
42 \cdot 7 \\
41 \cdot 3 \\
48 \cdot 0 \\
33 \cdot 3\end{array}$ & $\begin{array}{l}\text { H1 } \\
\text { H2 } \\
\text { H3 } \\
\text { H4 } \\
\text { H5 } \\
\text { H6 } \\
\text { H7 } \\
\text { H8 } \\
\text { H9 } \\
\text { H10 } \\
\text { H11 }\end{array}$ & $\begin{array}{l}45 \cdot 3 \\
41 \cdot 3 \\
57 \cdot 3 \\
50 \cdot 7 \\
41 \cdot 3 \\
50 \cdot 6 \\
44 \cdot 0 \\
52 \cdot 0 \\
48 \cdot 0 \\
45 \cdot 3 \\
40 \cdot 0 \\
11 \\
46 \cdot 9(5 \cdot 4)\end{array}$ & $\begin{array}{l}\text { HD1 } \\
\text { HD2 } \\
\text { HD3 } \\
\text { HD4 } \\
\text { HD5 } \\
\text { HD6 } \\
\text { HD7 } \\
\text { HD8 } \\
\text { HD9 }\end{array}$ & $\begin{array}{l}45 \cdot 3 \\
37 \cdot 3 \\
41 \cdot 3 \\
45 \cdot 3 \\
38 \cdot 7 \\
44 \cdot 0 \\
40 \cdot 0 \\
40 \cdot 0 \\
42 \cdot 7\end{array}$ \\
\hline
\end{tabular}

Table 5 Neuronal numerical density $\left(\times 10^{3}\right.$ per $\left.\mathrm{mm}^{3}\right) \mathrm{CA} 4$ region.

\begin{tabular}{|c|c|c|c|c|c|}
\hline \multicolumn{2}{|l|}{ Control group } & \multicolumn{2}{|c|}{ HIV Group } & \multicolumn{2}{|c|}{ HD Group } \\
\hline $\begin{array}{l}\text { Patient } \\
\text { Number }\end{array}$ & $\begin{array}{l}\text { Number of } \\
\text { neurons }\end{array}$ & $\begin{array}{l}\text { Patient } \\
\text { number }\end{array}$ & $\begin{array}{l}\text { Number of } \\
\text { neurons }\end{array}$ & $\begin{array}{l}\text { Patient } \\
\text { number }\end{array}$ & $\begin{array}{l}\text { Number of } \\
\text { neurons }\end{array}$ \\
\hline $\begin{array}{l}\text { C1 } \\
\text { C2 } \\
\text { C3 } \\
\text { C4 } \\
\text { C5 } \\
\text { C6 } \\
\text { C7 } \\
\text { C8 } \\
\text { C9 }\end{array}$ & $\begin{array}{l}\mathbf{4 4 \cdot 0} \\
34 \cdot 7 \\
36 \cdot 0 \\
36 \cdot 0 \\
34 \cdot 7 \\
37 \cdot 3 \\
40 \cdot 0 \\
38 \cdot 7 \\
38 \cdot 7\end{array}$ & $\begin{array}{l}\text { H1 } \\
\text { H2 } \\
\text { H3 } \\
\text { H4 } \\
\text { H5 } \\
\text { H6 } \\
\text { H7 } \\
\text { H8 } \\
\text { H9 } \\
\text { H10 } \\
\text { H11 }\end{array}$ & $\begin{array}{l}52 \cdot 0 \\
46 \cdot 7 \\
56 \cdot 0 \\
44 \cdot 0 \\
36 \cdot 0 \\
37 \cdot 3 \\
34 \cdot 7 \\
30 \cdot 7 \\
34 \cdot 7 \\
32 \cdot 0 \\
37 \cdot 3 \\
11 \\
40 \cdot 1(8 \cdot 4)\end{array}$ & $\begin{array}{l}\text { HD1 } \\
\text { HD2 } \\
\text { HD3 } \\
\text { HD4 } \\
\text { HD5 } \\
\text { HD6 } \\
\text { HD7 } \\
\text { HD8 } \\
\text { HD9 }\end{array}$ & $\begin{array}{l}41 \cdot 3 \\
34 \cdot 7 \\
34 \cdot 7 \\
34 \cdot 7 \\
40 \cdot 0 \\
34 \cdot 7 \\
38 \cdot 7 \\
37 \cdot 3 \\
40 \cdot 0\end{array}$ \\
\hline
\end{tabular}

four areas quantified compared with that in the control group, although the mean neuronal density in all areas is consistently higher than in the controls.

The striking and significant difference between the groups is seen in one region of the hippocampus. In the HD group the neuronal density in the CA1 region $(37.5$ $(5 \cdot 0) \times 10^{3}$ per $\left.\mathrm{mm}^{3}\right)$ is significantly less $(\mathrm{p}<$ 0.001 ; Student's $t$ test) than that observed in either the control $\left(57.9(15.4) \times 10^{3}\right.$ per $\left.\mathrm{mm}^{3}\right)$ or HIV group $\left(70 \cdot 1(13.4) \times 10^{3}\right.$ per $\mathrm{mm}^{3}$. This difference represents a neuronal loss of some $35 \%$. In the other regions quantified, the neuronal density in the HD group is not significantly different from the control or HIV group, although the mean values are consistently less than those in the controls.

An analysis of variance was carried out on the data for the two HIV subgroups and the control group. This showed that neither subgroup was significantly different from controls nor was there any significant difference between the subgroups in respect of any of the hippocampal regions quantified.

\section{Discussion}

This is the first quantitative study to have revealed cell loss of $35 \%$ in the hippocampus in HD and shows the changes to be restricted to area CA1. Little attention has been paid to hippocampal changes in $\mathrm{HD}$, since an early study $^{20}$ reported cell density to be normal. However, a more recent morphometric study of macroscopic sections from 30 cases of HD has reported a reduction of hippocampal area of some $20 \%$ compared with controls, ${ }^{12}$ and cited the early study ${ }^{20}$ as evidence of normal cell density. The authors explain this apparent discrepancy between reduction of area and normal neuronal density as being a result of a combination of neuronal loss and a proportionate tissue shrinkage. Moreover, one of the authors has stated elsewhere "to have been more impressed by the normality of the hippocampus than by any abnormality",21 and commented that the use of sophisticated techniques may reveal changes in the hippocampus not yet detected. The present study which has used a recently developed technique for assessing neuronal density would support this statement since it has detected a reduction in neuronal density in one area of the hippocampus. In addition, since CAl accounts for a substantial proportion of the total hippocampal volume, ${ }^{18}$ a $35 \%$ reduction of neuronal density in CA1 could account in part for the $20 \%$ reduction in hippocampal area previously reported. ${ }^{12}$

In our study there are insufficient details to assess clinically the degree of dementia in the HD and HIV infected patients but the neuronal loss in $\mathrm{HD}$ is a potential cause of dementia. Huntington's disease, ${ }^{22}$ and more recently, HIV associated dementia, ${ }^{2}$ have both been clinically labelled as subcortical dementias. However, pathologically, the earlier studies ${ }^{-11}$ showing neuronal loss in the frontal cortex in both conditions, together 
Table 6 Mean (SD) neuronal numerical density in four areas of the hippocampus in control, HIV and HD groups.

\begin{tabular}{|c|c|c|c|c|}
\hline \multirow[b]{2}{*}{ Patient group } & \multicolumn{4}{|c|}{ Cell density $\left(\times 10^{-3} \mathrm{~mm}^{-3}\right)$} \\
\hline & Dentate & $C A 1$ & $C A 3$ & $C A 4$ \\
\hline $\begin{array}{l}\text { Controls }(\mathrm{n}=9) \\
\text { Mean }(\mathrm{SD})\end{array}$ & 389 (105) & $57 \cdot 9(15 \cdot 4)$ & $43 \cdot 3(5 \cdot 5)$ & $37 \cdot 8(3 \cdot 0)$ \\
\hline $\begin{array}{l}\text { HIV Infected }(n=11) \\
\text { Mean }(\mathrm{SD})\end{array}$ & $452(99)$ & $70 \cdot 1(13 \cdot 4)$ & $46.9(5.4)$ & $40 \cdot 1(8 \cdot 4)$ \\
\hline $\begin{array}{l}\text { Huntington's disease ( } \\
\text { Mean (SD) }\end{array}$ & $\begin{array}{l}=9) \\
378(15)\end{array}$ & $37 \cdot 5^{\star \star}(5 \cdot 0)$ & $41.6(2.9)$ & $37 \cdot 3(2 \cdot 7)$ \\
\hline
\end{tabular}

$\star \star$ Significantly different from control $\mathrm{t}=4 \cdot 19 ; \mathrm{p}<0.001$ (Student's $t$ test).

with the present study showing neuronal loss in the hippocampus appear to raise some doubt that the dementias are solely subcortical, since all show that there is cortical pathology in addition to the subcortical components.

The selective vulnerability of hippocampal regions has not yet been fully explained, but the CAl field is more vulnerable to damage than other areas. For example CA1 is preferentially affected in a variety of conditions such as hypoxia, ${ }^{23}$ Alzheimer's disease, ${ }^{24}$ and Pick's disease. ${ }^{25}$ Thus the present findings in HD would confirm the selective vulnerability of this area.

The underlying mechanisms of selective neuronal damage in HD remains uncertain, although it has been proposed that an excitatory neurotransmitter, glutamate, ${ }^{26}$ and its analogues such as quinolinic acid ${ }^{27}$ may act as neurotoxins. In vitro studies using rat hippocampal cell cultures ${ }^{26}$ have shown dentate granule cells to be relatively resistant to glutamate-induced neurodegeneration, while cells from CA1 and CA3 were significantly more vulnerable. It was further shown that the vulnerable, but not the resistant, neurons expressed glutamate receptors which mediated large rises in intracellular calcium and subsequent degeneration. In $\mathrm{HD}$ a reduction of glutamate receptors on striatal neurons has been reported ${ }^{28}$ which would suggest that glutamate metabolism may have an important role in the pathogenesis of the cell loss in CAl seen in our study.

Although there is no significant difference in the neuronal numerical density, in any of the regions examined, between the HIV group and controls the values are consistently higher in the former group. This may be a reflection of the difference in the mean ages of the two groups. Although this difference is not significant, the mean for the HIV group is some 10 years less than the controls, and neurons decrease by some $3.6 \%$ per decade in the CAl region ${ }^{29}$ of the hippocampus.

The absence of hippocampal neuronal loss in the HIV group is interesting as it may provide an indication that the mechanism of cell damage in AIDS is different from that in HD, or may simply reflect a difference in duration of the disease processes. Although the duration of the symptoms is unknown in the HIV group, it is likely to be considerably shorter than the mean duration of $9 \cdot 7$ years in the HD group. Thus it is possible that the patients with HD died at an advanced stage of dementia by which time the hippocampus was involved, whereas the HIV patients died of other complications at an earlier stage of the disease before hippocampal involvement. Our study was retrospective and there is a paucity of information regarding the cognitive status of the patients. It is hoped, however, that a prospective study, being carried out at present, will address this problem.

These findings contribute to the understanding of the mechanism of dementia in both AIDS patients and in Huntington's disease and further delineate and quantify the extent of the neuropathological lesions in both conditions. It is anticipated that a further comparative study of selective neuronal loss in HIV infection and HD will lead to a better understanding of these diseases.

The authors gratefully acknowledge the assistance of Drs I Janota, P J Luthert and M Honavar; the technical assistance of Mrs $\mathrm{H}$ Barnes; and the assistance from Miss J Davies of the MRC National AIDS Neuropathology Database and Central Brain Tissue Bank, and from Dr N Cairns of the MRC Alzheimer's Disease Brain Bank. This work was partly funded Alzheimer's Disease Brain Bank. This work was partly funded by the Medical Research Council and the authors are most
grateful to the Mason Medical Foundation for financial supgrateful to the Mas
port for equipment.

1 Snider WD, Simpson DM, Nielsen S, Gold JWM, Metroka CE, Posner JB. Neurological complications of acquired immunodeficiency syndrome: analysis of 50 patients. Ann Neurol 1983;14:403-18.

2 Maj M. Organic mental disorders in HIV-1 infection. AIDS 1990;4:831-40.

3 Lang W, Miklossy J, Deruaz JP, et al. Neuropathology of the acquired immunodeficiency syndrome (AIDS): a report of 135 consecutive autopsy cases from report of 135 consecutive autopsy cases
Switzerland. Acta Neuropathol 1989;77:379-90.

4 Budka H. Neuropathology of human immunodeficiency virus infection. Brain Pathol 1991;1:163-75.

5 Catalan J. HIV-associated dementia: a review of some conceptual and terminological problems. Int Rev Psychiat 1991;3:321-30.

6 Price RW, Sidtis JJ, Brew BJ. AIDS dementia complex and HIV-1 infection: A view from the clinic. Brain Pathol 1991;1:155-62.

7 Navia BA, Cho E-S, Petito CK, Price RW. The AIDS dementia complex: II. Neuropathology. Ann Neurol 1986;19:525-35.

8 Budka H, Constanzi G, Cristina S, et al. Brain pathology induced by infection with the human immunodeficiency virus (HIV). A histological, immunocytochemical and electron microscopical study of 100 autopsy cases. Acto Neuropathol 1987;75:185-198.

9 Everall IP, Luthert PJ, Lantos PL. Neuronal loss in the frontal cortex in HIV infection. Lancet 1991;337: 1119-21.

10 Sotrel A, Myers RH. Morphome tric analysis of prefrontal cortex in Huntington's disease (HD). $\mathcal{F}$ Neuropathol Exp Neurol 1990;49:346.

11 Cudkowicz BS, Kowall NW. Degeneration of pyramidal projection neurons in Huntington's disease cortex. Ann Neurol 1990;27:200-4.

12 de la Monte SM, Vonsattel JP, Richardson EP Jr Morphometric demonstration of atrophic changes in the cerebral cortex, white matter, and neostriatum in 516-25.

13 Lantos PL. Ageing and dementias. In: Weller RO, ed. Systemic Pathology, 3rd Ed, vol 4. Nervous system, muscle and eyes. Edinburgh: Churchill Livingstone, muscle and ey

14 Folstein SE. The cognitive disorder. Huntington's disease: a disorder of families. Baltimore: Johns Hopkins Press, 1989:32-48.

15 Sterio DC. The unbiased estimation of number and size of arbitrary particles using the disector. $\mathcal{f}$ Microscopy 1984;134:127-36.

16 Masliah E, Ge N, Morey M, DeTeresa R, Terry RD, Wiley CA. Ccrtical dendritic pathology in human immunodefic:- .zy virus encephalitis. Lab Invest 1992; 66:285-91.

17 Duvernoy HM. The human hippocampus. An atlas of applied anatomy. Munchen: J F Bergmann Verlag 1988.

18 West MJ, Gundersen HJG. Unbiased stereological estimation of the number of neurons in the human hippocampus. F Comp Neurol 1990;296:1-22.

19 Everall IP, Luthert PJ, Lantos PL. Neuronal number and volume alterations in the neocortex of HIV infected 
individuals. $f$ Neurol Neurosurg Psychiatry 1992; (in press)

20 Dunlap CB. Pathologic changes in Huntington's Chorea with special reference to the corpus striatum. Arch Neurol Psychiat 1927;18:867-943.

21 Scully RE, Mark EJ, McNeely WF, McNeely BU. Case records of the Massachusetts General Hospital: Case 2-1992. New Eng $\mathfrak{F}$ Med 1992;326:117-125.

22 Gupta SR, Naheedy MH, Young JC, Ghobrial M, Rubino FA, Hindo W. Periventricular white matter changes and dementia. Clinical, neuropsychological, radiological and pathological correlation. Arch Neurol 1988;45: and pathol 637 .

23 Brierly JB, Graham DI. Hypoxia and vascular disorders of the central nervous system. In: Adams JH, Corsellis JAN, Duchen LW. Greenfield's Neuropatholo

24 Ball MJ. Topographic distribution of neurofibrillary tangles and granulovacuolar degeneration in hippocampal cortex of aging and demented patients. Acta Neuropath (Berl) $1978 ; 42: 73-80$

25 Ball MJ. Topography of Pick inclusion bodies in hippocampi of demented patients. A quantitative study. $\mathcal{f}$ Neuropathol Exp Neurol 1979;38:614-20.

26 Mattison MP, Guthrie PB, Kater SB. Intrinsic factors in the selective vulnerability of hippocampal neurons. Prog Clin Biol Res 1989;317:333-51.

27 Schwarcz R, Foster AC, French ED, Whetsell WO, Kohler C. Excitotoxic models for neurodegenerative disorders. Life Sci 1984;35:19-32.

28 London ED, Yamamura HI, Bird ED, Coyle JT. Decreased receptor binding sites for kainic acid in brains of patients with Huntington's disease. Biol Psychiat 1981;16:155-62.

29 Miller AKH, Alston RL, Mountioy CQ, Corsellis JAN. Automated differential cell counting on a sector of the normal hippocampus: The influence of age. Neuropathol Appl Neurobiol 1984;10:123-41. 